\title{
The reality of the donkey's exploitation for the hide trade in Brazil: disease outbreaks and animal welfare compromised in rescued donkeys
}

\author{
A realidade da exploração de jumentos para exportação de pele no \\ Brasil: surtos sanitários e bem-estar animal comprometido em asininos \\ resgatados
}

Lucas Santana da Fonseca $^{1}$ (D); Aline Rocha Silva²; Frederico Augusto Mazzocca Lopes Rodrigues ${ }^{3}$; Sidnei Miyoshi Sakamoto"; Vania de Fátima Plaza Nunes; ; Adroaldo José Zanella3; Chiara Albano de Araujo Oliveira ${ }^{6}$; Pierre Barnabé Escodro ${ }^{7}$

\author{
${ }^{1}$ Universidade Federal de Alagoas, Programa de Pós Graduação em Ciência Animal, Viçosa - AL, Brazil \\ ${ }^{2}$ Universidade Federal da Bahia, Residência em Clínica Médica de Grandes Animais, Salvador - BA, Brazil \\ ${ }^{3}$ Universidade de São Paulo, Faculdade de Medicina Veterinária e Zootecnia, Departamento de Medicina Veterinária Preventiva e Saúde \\ Animal, São Paulo - SP, Brazil \\ ${ }^{4}$ Universidade Federal Rural do Semi-Árido, Departamento de Ciências Animais, Mossoró - RN, Brazil \\ 5 Fórum Nacional de Proteção e Defesa Animal, Jundiaí - SP, Brazil \\ ${ }^{6}$ Universidade Federal da Bahia, Escola de Medicina Veterinária e Zootecnia, Salvador - BA, Brazil \\ ${ }^{7}$ Universidade Federal de Alagoas, Curso de Medicina Veterinária, Viçosa - AL, Brazil
}

\begin{abstract}
About 800 donkeys that were confined in a restrictive area used in a manner comparable to a warehouse for receiving donkeys for slaughter were abandoned. After receiving reports of mistreatment, civilians acted to save the animals. A task force was organized that planned veterinary and zootechnical actions and activities for daily health management, feeding, and clinical care to attend to the abandoned donkeys. Positive cases were diagnosed for glanders, equine infectious anemia, equine herpesvirus, and equine babesiosis. The objective of this communication is to bring to the attention of the scientific community the interventions in the area of animal health and welfare, to address the episode of northeast donkeys that were victims of international trade. It is fundamental to change the approach related to the management of donkeys in Brazil, and appeal to the necessity to identify ethical and sustainable ways to incorporate donkeys in Brazil in the $21^{\text {st }}$ century.
\end{abstract}

Keywords: Donkey welfare. Ejiao. Zoonosis. Sanitary emergency. One welfare.

\section{RESUMO}

Cerca de 800 jumentos confinados em uma área utilizada como entreposto de recebimento e encaminhamento de jumentos para abate foram abandonados. Após denúncias de maus tratos, a sociedade civil atuou para salvar os animais. Foi constituída uma força tarefa que planejou ações e atividades veterinárias e zootécnicas atuando diariamente no manejo sanitário, na alimentação e nos cuidados clínicos na assistência aos jumentos abandonados. Foram diagnosticados casos positivos de mormo, anemia infecciosa equina, herpesvírus equino e babesiose equina. O objetivo desta comunicação foi relatar para a comunidade científica as intervenções nas áreas de saúde e bem-estar animal no episódio dos jumentos nordestinos vítimas do comércio internacional. É fundamental mudar a abordagem em relação ao manejo de jumentos no Brasil e apelar para a necessidade de identificar maneiras éticas e sustentáveis de incorporar os jumentos no Brasil do século 21.

Palavras-chave: Bem-estar de jumentos. Ejiao. Zoonose. Emergência sanitária. Bem-estar único. 


\section{Correspondence to:}

Lucas Santana da Fonseca

Universidade Federal de Alagoas, UFAL, Programa de Pósgraduação em Ciência Animal

BR-104, $\mathrm{km} 85, \mathrm{~s} / \mathrm{n}$

CEP: 57100-000, Rio Largo, AL, Brasil

E-mail: lucasfonseca1989@gmail.com

Received: September 10, 2020

Approved: January 26, 2021

How to cite: Fonseca LS, Silva AR, Rodrigues FAML, Sakamoto SM, Nunes VFP, Zanella AJ, Oliveira CAA, Escodro PB. The reality of the donkey's exploitation for the hide trade in Brazil: disease outbreaks and animal welfare compromised in rescued donkeys. Braz J Vet Res Anim Sci. 2021;58(special issue):e174674. https://doi. org/10.11606/issn.1678-4456.bjvras.2021.174674

The mechanization of transport and agricultural activities contributed to the decrease in the number of working donkeys, as well as to the increasing abandonment of animals in the Brazilian Northeast (Carneiro et al., 2018). Thus, donkeys are kept in vulnerable conditions and often are collected surreptitiously for the slaughter and export of hides and meat, without sanitary control, and without following transport standards and welfare conditions (Fonseca et al., 2020). China began importing animal products mainly from Brazil and countries in Africa. Due to this, in the exporting countries, a decline of $28 \%$ in the herd was observed between 2007 and 2017 (Leste-Lasserre, 2019).

The exploitation of these animals without control can be an important factor in the extinction of the species. FAO estimates point to a decline in the donkey population in Latin America between 1966 and 2016. In Brazil, this reduction was $37.08 \%$ in the period (Carneiro et al., 2018).

In this context, about 800 donkeys were abandoned where they were kept in a restricted area of approximately 15 hectares in the municipality of Canudos-BA, Brazil. The place was used as a warehouse to receive donkeys for slaughter. The animals were collected (bought from small rural producers for low values and/or captured on open highways and in cities) by truck drivers from the Brazilian Northeast regions and taken to "warehouses" in the Northeast Brazilian state of Bahia. They were abandoned because of the legal suspension of slaughter, from December 2018 to September 2019.

After the death of many animals and accusations of mistreatment made by the local population to the State Public Prosecutor's Office, an inspection was made by the health and environment surveillance agencies (Agribusiness
Defense Agency of Bahia [ADAB], Institute of Environment and Water Resources [INEMA] and the Brazilian Institute of Environment and Renewable Natural Resources [IBAMA]), who carried out inspections, which resulted in the closure of the farm for serological examinations for equine infectious anemia (EIA) and glanders. However, the organizations of the State of Bahia, legally responsible for the animals and the situation, claimed to be unable to take care of the donkeys.

Given the circumstances, the NGO, the National Forum for the Protection and Defense of Animals (FNPDA), a member of the National Front for the Defense of Donkeys movement, assumed the temporary guardianship of the animals. Soon after, a group of researchers from the University of São Paulo, Federal University of Bahia, Federal University of Alagoas, Federal Rural University of SemiArid, and organizations of animal protection, were united in a Task Force. They sought to act and minimize the critical situation that the animals were in and took responsibility for the daily actions/tasks of health management, food, and clinical and surgical care. The international NGO, The Donkey Sanctuary, provided technical and financial help to maintain the activities. Financial collections and lawsuits were managed by FNDJ lawyers.

The official sanitary control action was performed by $\mathrm{ADAB}$, which initially collected blood from 634 animals for the EIA and glanders tests. The situation of the animals and the environment was critical and required organization and effort from the task force to reduce mortality and promote animal health and welfare. Donkeys died daily throughout the area, with dogs and vultures feeding on the carcasses. For the actions in the period from March 19 to November 20 , technical teams were organized.

The intensive daily activities were performed by a permanent technical team of two veterinarians and an assistant. The activities consisted of food management (providing hay and mineral salt), water supply (filling and cleaning collective drinkers), identification (ear tags), body condition score follow-up, vaccination (rabies), parasitic control (doramectin 1\%), clinical examinations and treatments (Figure 1). A thorough evaluation of all animals and a search for debilitated animals was carried out daily. Therapeutic daily assistance to downed animals included interventions with antibiotics and anti-inflammatory drugs, fluid therapy, administration of polyvitamins, analgesia, and wound dressings. Euthanasia was sometimes performed to alleviate animal suffering.

The area where the donkeys were kept did not provide grazing opportunities but included only the native vegetation of Caatinga, which was already degraded by overcrowding. 


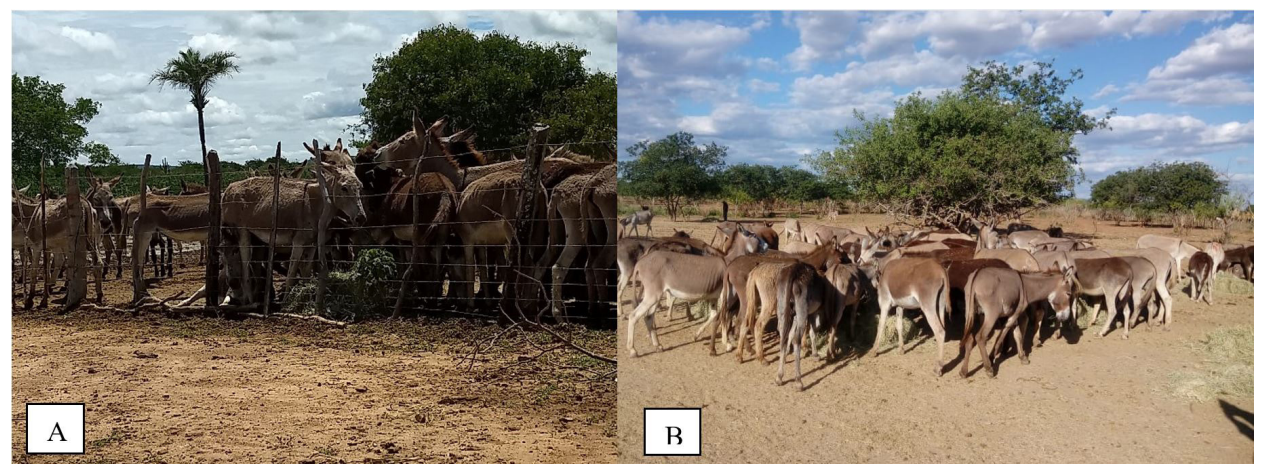

Figure 1 - A) Agglomerated animals on a farm in the municipality of Canudos-BA, a warehouse for slaughter. B) Supply of grass hay twice a day after the arrival of the Task Force.

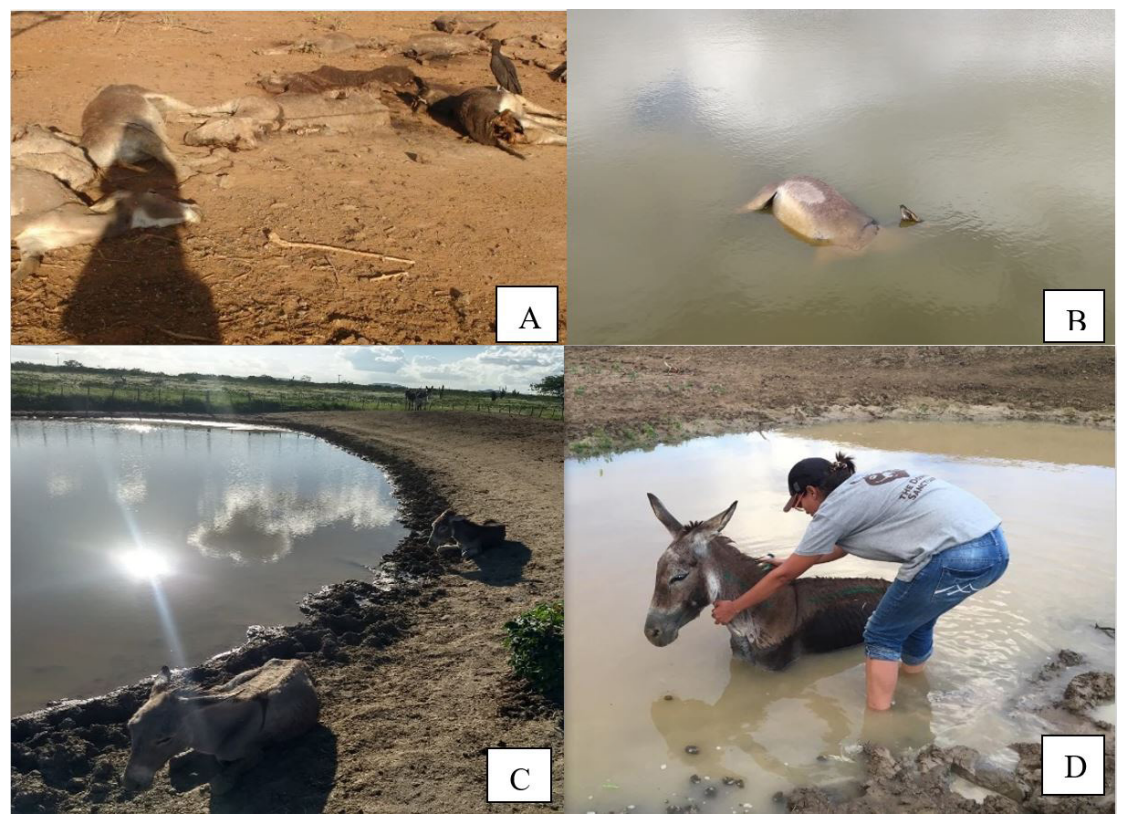

Figure 2 - A) Bodies of donkeys subjected to mistreatment and outbreak of diseases (February 2019). B) Animal drowned in the "watering area". C) Downed animals, without being able to stay in quadrupedal position without nursing aid. D) Donkey being saved by veterinary professional Aline Rocha, after being "stranded" in the dam (strenuous daily routine work).

The only water source had margins of mud that several times caused falls, jamming, and sometimes even the death of debilitated animals (Figure 2A, 2B, 2C, and 2D).

The clinical and surgical activities were carried out by the technical support team with an adapted laboratory assembly for evaluation of globular volume, total protein, serum fibrinogen, and separation of biological material. One of the objectives was the selection of animals suitable for castration, as well as basic assistance in clinical care (Figures $3 \mathrm{~A}$ and $3 \mathrm{~B}$ ).

Thirty-one castrations were performed, divided into two technical visits. The animals underwent clinical and hematological evaluation for the selection of individuals suitable for the surgical procedure. The technique used was latero-scrotal. In most of the animals, copro-parasitological exams were performed. The emergency surgeries performed were three surgeries of ulcerated skin hyperplasia (tumors with bleeding and secretion), repair of rectal prolapse in three animals, medial patellar desmotomy in an animal with dorsal patellar fixation, and surgical treatment of animals with a perforated corneal ulcer. Hoof trimming of more than 30 animals and clinical care of 32 animals with lameness were also performed.

In the first examination, nine animals tested positive for glanders, and five tested positive for EIA. These were euthanized by $\mathrm{ADAB}$. The tests were repeated until two consecutive tests were negative according to the Normative Instructions of the Brazilian Ministry of Agriculture. The farm reopen occurred after six months, and six blood samples were collected, with a total of 10 animals positive for glanders and 14 for EIA. The first results of the EIA and glanders tests were only released 60 days after the first collection, and verified the seriousness of the episode, not only for the donkeys, but also for the technical teams exposed to the health risks of zoonosis, and for the at-large equid industry of the State of Bahia and of the other States where the animals were captured and transported from until they arrived in Canudos. After the critical period of the first two 
months, the count was 415 donkeys, of which 150 were males (85 intact and 65 castrated), and 265 were females, with ages ranging from less than one year to over 30 years.

Other infectious diseases, such as herpesvirus, were diagnosed, as there were many cases of miscarriages/disease (14 miscarriages), jaundiced animals, and ophthalmic conditions (ulcers, uveitis). Due to the general conditions of the animals, there was a confirmation of hemoparasitosis caused by parasites, such as Babesia sp., which causes anemia, cachexia, and death, among others.

The challenges encountered were enormous because of the history of neglect of animals destined for slaughter without any action of health control and nutritional management. Despite the difficulties, basic organized strategies were successful to promote better conditions for the donkeys. However, despite several approaches carried out by the task force to improve the health and welfare of the group of donkeys, the mortality remained high.

Due to the difficulties of infrastructure, nonexistent pasture supply, and inadequate space for the animals, the Ministry of Agriculture, Livestock, and Supply (MAPA) and the $\mathrm{ADAB}$ authorized the transfer of donkeys to another property. The transfer of the animals was carried out in a planned and monitored manner to ensure the safety of the journey of the animals. In four days, the 207 surviving donkeys, of which 20 animals were in serious condition and with an unfavorable prognosis, were transported to other farms (Figures 4A and 4B), the indication of euthanasia was not realized because of the lack of medications.

The purpose of the transfer was to reduce mortality, with the offer of adequate good quality pasture, and the possibility of separating the animals into categories for more specific care. At the new site, strategies to promote animal welfare measures were outlined taking into account nutrition, water intake, natural behavior, and internal equid medicine.

The donkeys were divided into groups of males and females and treatment areas. The paddocks were formed by pastures with several species of vegetation and supplied by good quality water in troughs and natural sources with firm water banks, which reduced the risk of accidents. It was possible to organize the veterinary medicine actions, with the most adequate storage, administration, and control of the treatment protocols for sick and/or debilitated animals. For this purpose, the donkeys were divided into three areas classified as shown in Figures 5A, 5B, and 5C.

In the first month of adaptation after the transfer, of the 20 animals that arrived in precarious conditions, 19 died, the remaining 180 donkeys, 67 males (40 castrated, 1 cryptorchid, and 26 stallions) and 113 females. The action of transferring

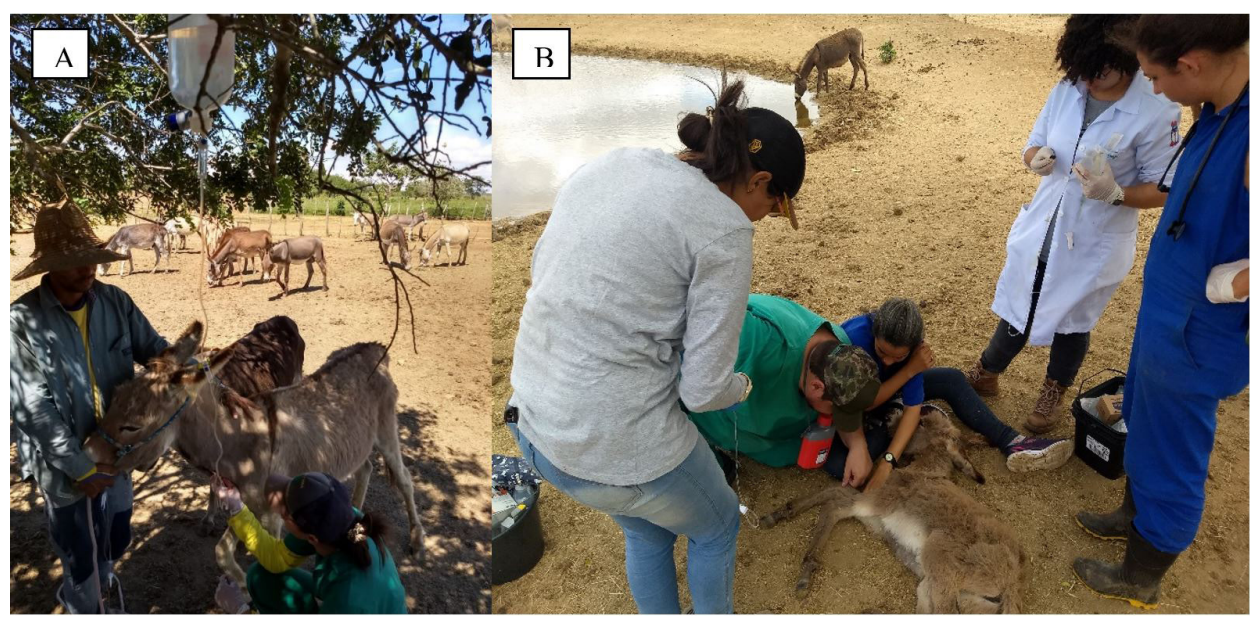

Figure 3 - A) Daily veterinary medical activities. B) clinical care for debilitated donkeys.

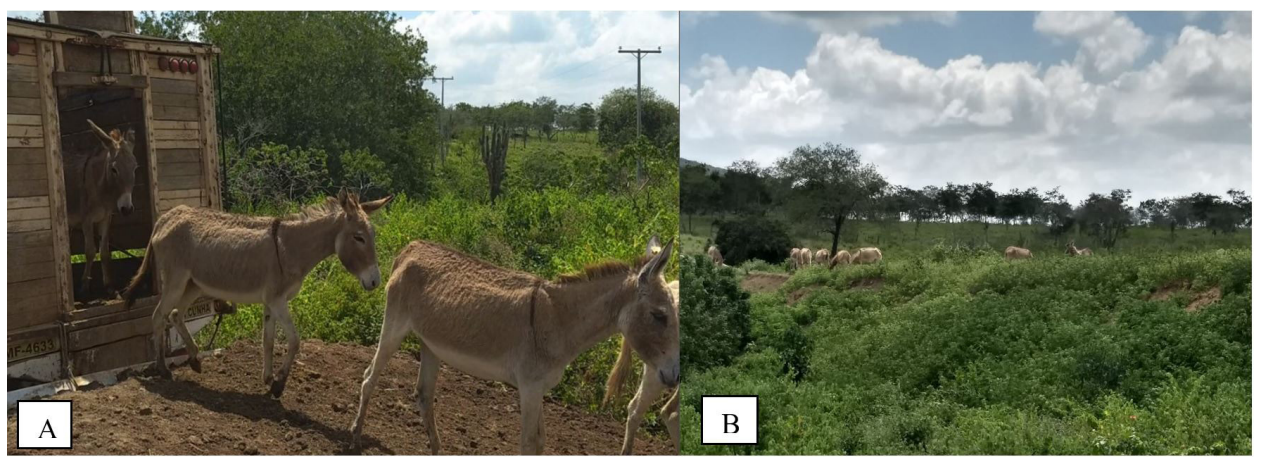

Figure 4 - A) Animals transported to other farms. B) grazing area where the animals were released. 


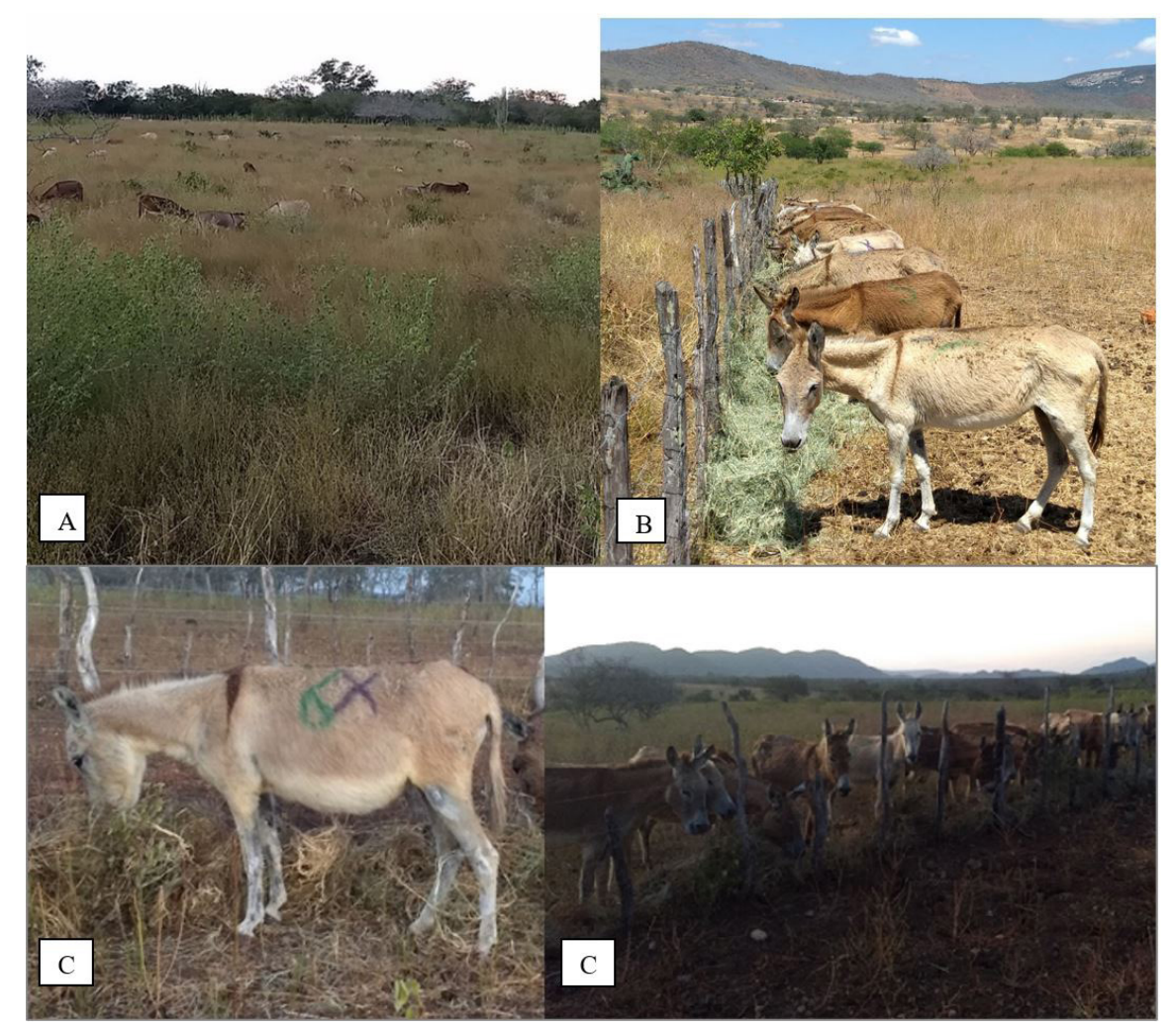

Figure 5 - A) Paddock area for healthy animals (low-risk area). B) Hay feeding animals in the medium risk area. C) Animals feeding on hay in the treatment of the high-risk area.

the animals, the new feeding conditions, implementation of sanitary measures, and collective management, was effective in reducing mortality for the remaining 180 donkeys who left site 1 in reasonable condition. In the first farm, the mortality rate was $50.12 \%$ (in 4 months), after the transference the mortality rate reduced to $13.04 \%$ (in 3 months). Considering the 19 animals already transferred in a critical state and subtracting these from the total of donkeys the mortality rate was $4.25 \%$.

A total of 175 donkeys from the original group were transferred to another farm, which adopted 30 donkeys and accepted the others temporarily until they would develop a condition where they could be forwarded to definitive homes. In this farm, the donkeys remained loose in an area of native Caatinga pasture, with mineral supplementation and safe access to quality water. At this point, there were 150 surviving donkeys, six of which would still need daily veterinary monitoring.

We believe that this report can help in future situations, not only regarding technical issues of veterinary medicine and animal science but especially when these actions are combined with legal actions involving animals under vulnerability, mistreatment, and multifactorial etiopathogenic diseases. This episode described the real conditions to which donkeys for the hide trade are submitted, resulting in high donkey mortality (about $80 \%$ ), and demonstrates that sanitary rules and traffic control were omitted for an indefinite period because of the history of facts related to the animals encountered in Canudos.

It is fundamental to change the approach to the management of these animals, which are emblematic of the development and resilience of the donkey population in the Northeast of Brazil. Novel strategies must be developed to integrate donkeys to the Brazil of the $21^{\text {st }}$ century, focusing on sustainable and ethical principles, since the skin and meat trade severely compromised the welfare and health of these animals. The Slaughter of donkeys is again legal in Brazil and requires the legal framework to protect these animals. Structured public policies that are conducted with responsibility and respect should be the center of decisions involving this trade.

\section{Conflict of interest}

The authors declare no conflict of interest.

\section{Ethics Statement}

We certify that the proposal entitled "Health of vulnerable donkeys in Canudos / Bahia", registered with no 21/2019, under the responsibility of the researcher Prof. Dr. Pierre Barnabé Escodro, which involves the use of animals belonging to the phylum Chordata, subphylum Vertebrata (except man), for the purposes of scientific research, is in accordance with the precepts of Law No. 11,794, of 
October 8, 2008, of Decree No. 6,899, of July 15, 2009, and with the rules issued by the National Council for the Control of Animal Experimentation (CONCEA), and was approved by the Ethics Committee on the Use of Animals of the Federal University of Alagoas (CEUA / UFAL ), in a meeting of 14 November 2019.

\section{Acknowledgements}

The authors thanks to ONGs Frente Nacional de Defesa dos Jumentos, Fórum Nacional de Proteção e Defesa Animal, União Defensora dos Animais-Bicho Feliz e The Donkey Sanctuary; a Universidade de São Paulo (USP), Universidade Federal da Bahia (UFBA), Universidade Federal

\section{References}

Carneiro GF, Lucena JEC, Barros LO. The current situation and trend of the donkey industry in South America. J Equine Vet Sci. 2018;65:106-10.http://dx.doi.org/10.1016/j.jevs.2018.03.007.

Fonseca LS, Nascimento RCM, Carvalho AD, Graboschii ACG, Vargas YGM, Silva AR, Escodro PB. O extrativismo de jumentos para exportação de pele no nordeste do Brasil: visão geral e aspectos sanitários. Ponta Grossa: de Alagoas (UFAL), Universidade Federal do Semi-Árido (UFERSA) e Centro Universitário INTA Sobral - UNINTA; ao Ministério Público da Bahia (MPBA), Ministério da Agricultura e Abastecimento (MAPA) e Agência de Defesa Agropecuária da Bahia (ADAB); aos colegas e profissionais Prof. Raimundo Barreto, Amanda Graboschii, Yana Vargas, Jeferson Luna, Hayanne Parlamento, Rayanne Medeiros, Adryano Carvalho, Yane Moreira, Esther Abihail Fuentes Arévalo, Jarbiane Gomes, Ivana Ferro, Jamisson Bispo, Juan Vitor Santos Brito, Ademir José da Silva Neto, Murilo Ramos Santiago, Paloma Sousa Bahia, Sharacelly Farias, Mariana Gameiro, Laura Pinseta, Patrícia Tatemoto, Vilton Santos Santiago, Gislane Brandão, Joyce Medeiros e Yuri Fernandes.

ATENA; 2020; p. 242-259. http://dx.doi.org/10.22533/ at.ed.124202404.

Lesté-Lasserre C. Donkeys face worldwide existential threat. Science. 2019;366(6471):1294-5. http://dx.doi.org/10.1126/ science.366.6471.1294. PMid:31831646.

Financial support: None. 